\title{
“RAINFALL EROSIVITY MAPPING AT DIFFERENT ALTITUDE SITES IN DUHOK GOVERNORATE"
}

\author{
Ghariba Y. Haji ${ }^{*}$ and AbdulsattaR H. Sulaiman ${ }^{* *}$ \\ *Dept. of Recreation and Ecotourism, College of Agricultural Engineering Sciences, University of Duhok, \\ Kurdistan region- Iraq. \\ ** Dept. of Soil and Water Sciences, College of Agricultural Engineering Sciences, University of Duhok, \\ Kurdistan region-Iraq.
}

(Received: September 25, 2019; Accepted for Publication: November 20, 2019)

\begin{abstract}
Rainfall erosivity (R) was determined by computation of rain erosivity factor that based on the recorded and analyzed rainfall data which was collected from the rain gauge stations (Duhok, Zawita, Ghlbuk, Swaratoka, Mangesh, Bamarney, Sarsink, Amadia, Batifa and Kani-Masi). Modified Fournier index (MFI) was calculated depending upon the monthly and annual rainfall for each of the ten stations, and then a map for annual rainfall erosivity was interpolated based on the multivariate pattern following the ordinary kriging method. The main purpose of this study is to estimate the erosivity factor and then to correlate the $R$ values with the elevation of study sited (rain gauge stations), then drawing the rain erosivity map by use GIS tool. Results showed that the relationships between $R$ and Altitude was weak as correlated in linear equation with $\left(r^{2}=0.168\right)$. The highest $R$ value was at Sarsink stations $(436 \mathrm{MJ} \mathrm{mm} / \mathrm{ha}$. $h . \mathrm{yr})$ although its elevation was $(1019 \mathrm{~m})$, While the highest elevation was at Kani-Masi stations $(1281 \mathrm{~m})$ but its $R$ value was only $(293.4 \mathrm{MJ} \mathrm{mm} / \mathrm{ha}$. h. $y r) . r^{2}$ between rainfall and $R$ was 0.821 which shows a moderately strong relationship.
\end{abstract}

KEYWORDS: Erosivity factor, Rainfall, Fournier index. GIS Map, Altitude https://doi.org/10.26682/ajuod.2019.22.2.21

\section{1. -INTRODUCTION}

$\mathbf{R}$ ainfall erosivity was defined by the computation of rain erosivity factors based on recorded and analysis rainfall data from rain gauges stations over a given period. Elwell (1981) uses rainfall energy to determine the erosivity factor for estimating soil loss in southern Africa. Hudson (1971) regarded that kinetic energy for rain falling at intensities of more than $25 \mathrm{~mm} / \mathrm{hr}$ to be more appropriate for estimating kinetic energy. Lal (1975) in Nigeria reported a better correlation with the product of total rainfall and the maximum 30-minute intensity. The erosivity index was used in the Universal Soil Loss Equation and then in the Revised Universal Soil Loss Equation to compute the annual average erosivity for the entire USA (Wischmeier \& Smith, 1978). There is some degree of correlation between erosivity power and amount of rainfall. A number of correlations have been established in localized conditions, for example in Malaysia, Morgan (1974) established the correlation between erosivity and the ten-year daily rainfall amounts. In Zimbabwe Elwell and Stocking (1975) obtained a reasonable agreement between erosivity and rainfall amount based on the idea of selecting only rainfalls within defined results of limited local application. Lo et al., (1985) found a correlation between mean annual rainfall and erosivity factor. In USA, Renard and Freimund (1994) used both mean annual precipitation and the modified Fournier index to estimate the $(\mathrm{R})$ factor. A modified version of Fournier index was introduced for the FAO to study soil degradation (Arnoldus, 1980), and the first approximation of a worldwide map of erosivity factor applied modified Fournier index (Kingu, 1980). Bulgarian experts (Nikolov, 1983) estimated the erosivity factor and draw an iso-erosion map of Northern of Iraq. Sheridan 
and Rosewell (2003) obtain a new (R) value contour map for Victoria which developed from empirical relationships between rainfall intensity, frequency and duration. From the basic nature of the input, such models can only give a first approximation of erosivity factor and more accurate estimations must depend on more detailed input.

Spatial distribution maps were found for natural and management erosion factors and to be the best value in the early stages of land management plans, allowing selection preferential areas where action against soil erosion is more urgent or where the remediation effort will have the highest revenue (Mart' inez et al., 2009). With the advent of GIS packages and the generalization of spatial interpolation techniques, maps of environmental parameters such as those relevant for soil erosion have become frequent. For example, several authors have used GIS'techniques to map the factors of the RUSLE equation by means of interpolation methods (Lim, 2005: L'opez-Vicente et al., 2008). Interpolation methods are tools for the determination of unknown values from data observed at known regions. Due to spare synoptic stations, it is necessary to indicate the erosivity index for locations to prepare maps (Khorsandi et al., 2012).

The main purposes of this study are to estimate erosivity factor values and correlated them with altitude and rainfall then create a rainfall erosivity maps by using GIS for the study locations include Duhok, Zawita, Ghlbuk, Swaratoka, Mangesh, Bamarney, Sarsink, Amadia, Batifa and Kani-Masi sites.

\subsection{Study area}

\section{MATERIALS \& METHODS}

The study area is illustrated ten sites were selected and coordinate as shown in Fig. (1). The lowest site was in Duhok $(569 \mathrm{~m})$ and highest one at Kani_ Masi site $(1281 \mathrm{~m})$ the area has shown different above sea level (msl). Distribution of annual precipitation in each site during the past ten years from 2008-2018 that ranged from $548.2 \mathrm{~mm}$ to $1038.8 \mathrm{~mm}$ in Duhok and Sarsink respectively at table (2).

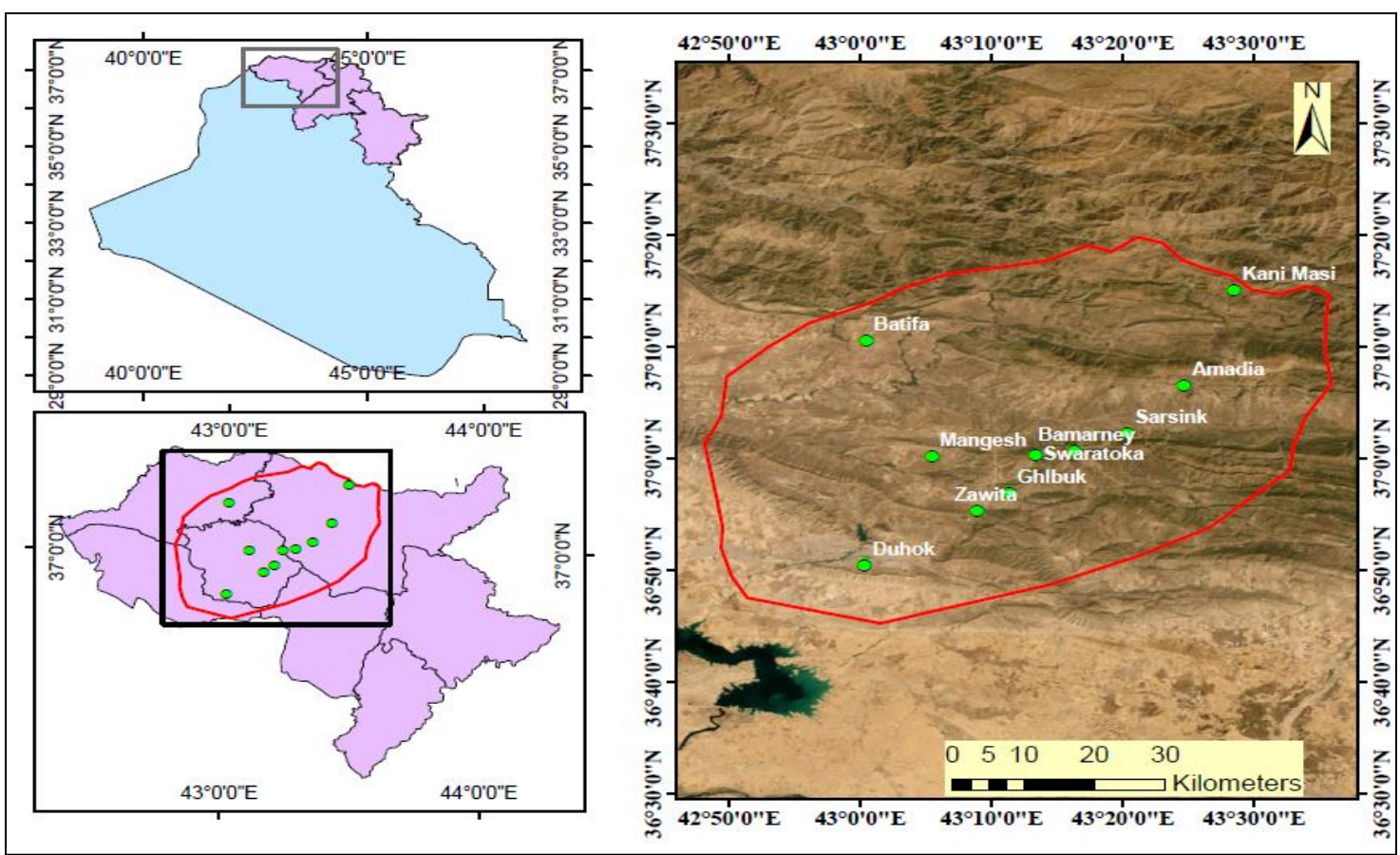

Fig. (1): Maps show the study sites 


\section{2. $R$ factor}

]The monthly precipitation data collected from each of the ten sites mentioned in table -1 for the years 2008-2018. These data used in modified Fournier index equation, (Amoldus, 1980): $\left(\mathrm{MFI}=\sum_{\mathrm{i}=1}^{12} \mathrm{p}^{2} / \mathbf{P}\right)$ Where $\mathrm{p}_{\mathrm{i}}$ is the monthly rainfall $(\mathrm{mm})$ and $\mathbf{P}$ is the annual rainfall in $\mathrm{mm}$. The obtained Results of all sites used to calculate $\mathrm{R}$ factor $(\mathrm{Yu}$ and Rosewell, 1996): $\left(\mathrm{R}=3.82 \mathrm{MFI}^{1.41} \mathrm{MJ}\right.$ $\mathrm{mm} / \mathrm{ha} \mathrm{h} \mathrm{yr}$ ). The researcher used a kriging method of interpolation to draw the rainfall erosivity maps (Governs, 1999).

Table (1): coordinates of the sites

\begin{tabular}{cccc}
\hline Stations & Longitude $(\mathrm{X})$ & Latitude $(\mathrm{Y})$ & Altitude $(\mathrm{m})$ \\
\hline Duhok & $43^{\circ} 02^{-} 00^{=}$ & $36^{\circ} 50^{-} 00^{=}$ & 569 \\
\hline Zawita & $43^{\circ} 08^{-} 28^{=}$ & $36^{\circ} 54^{-} 16^{=}$ & 890 \\
\hline Glbuk & $43^{\circ} 11^{-} 34^{=}$ & $36^{\circ} 56^{-} 88^{=}$ & 996 \\
\hline Swaratoka & $43^{\circ} 13^{-} 36^{=}$ & $37^{\circ} 00^{-} 34^{=}$ & 1211 \\
\hline Mangesh & $43^{\circ} 0545^{=}$ & $37^{\circ} 02^{-} 05^{=}$ & 957 \\
\hline Sarsink & $43^{\circ} 20^{-} 35^{=}$ & $37^{\circ} 02^{-} 30^{=}$ & 1019 \\
\hline Bamarney & $43^{\circ} 16^{-} 30^{=}$ & $37^{\circ} 06^{-} 51$ & 1164 \\
\hline Amadia & $43^{\circ} 29^{-} 13^{=}$ & $37^{\circ} 05^{-} 22^{=}$ & 1202 \\
\hline Batifa & $43^{\circ} 00^{-} 27^{=}$ & $37^{\circ} 10^{-} 32^{=}$ & 879 \\
\hline Kani_Masi & $43^{\circ} 08^{-} 28^{=}$ & $37^{\circ} 13^{-} 43^{=}$ & 1281 \\
\hline
\end{tabular}


Table (2): Monthly precipitations in the studied stations

\begin{tabular}{|c|c|c|c|c|c|c|c|c|c|c|c|c|c|}
\hline \multirow[t]{2}{*}{ Stations } & \multicolumn{12}{|c|}{ Month } & \multirow{2}{*}{$\begin{array}{c}\text { Total } \\
\text { Precipitations } \\
(\mathrm{mm})\end{array}$} \\
\hline & Jan. & Feb. & Mar. & Apr. & May & Jun. & Jul. & Aug. & Sep. & Oct. & Nov. & Dec. & \\
\hline Duhok & 111.6 & 69.2 & 67.2 & 50.4 & 24.9 & 2.2 & 1.0 & 0.3 & 4.6 & 29.7 & 77.3 & 109.8 & 548.2 \\
\hline Zawita & 189.7 & 101.8 & 97.2 & 65.6 & 37.6 & 1.2 & 1.4 & 0.0 & 7.5 & 43.0 & 100.8 & 175.1 & 820.8 \\
\hline Glbuk & 116.3 & 152.4 & 138.1 & 104.6 & 50.35 & 0.7 & 0.2 & 0.2 & 1.2 & 23.2 & 78.4 & 118.5 & 784.2 \\
\hline Swaratoka & 161.4 & 123.2 & 93.6 & 74.9 & 39.8 & 4.0 & 0.0 & 3.0 & 16.2 & 51.4 & 93.2 & 130.5 & 791.2 \\
\hline Mangesh & 118.2 & 144.5 & 133.8 & 107.1 & 51.4 & 2.2 & 0.6 & 0.6 & 1.6 & 27.9 & 82.0 & 117.8 & 787.7 \\
\hline Sarsink & 211.2 & 137.4 & 149.7 & 101.3 & 52.7 & 4.2 & 0.0 & 0.2 & 7.8 & 67.8 & 117.4 & 189.1 & 1038.8 \\
\hline Bamarney & 117.0 & 158.1 & 143.1 & 119.8 & 59.1 & 1.9 & 0.6 & 0.5 & 1.5 & 33.5 & 92.1 & 118.8 & 845.9 \\
\hline Amadia & 148.0 & 108.4 & 137.4 & 97.1 & 45.2 & 3.3 & 0.9 & 0.0 & 9.7 & 66.7 & 93.2 & 147.9 & 857.8 \\
\hline Batifa & 120.9 & 135.3 & 127.4 & 107.0 & 50.2 & 2.9 & 0.7 & 0.7 & 1.8 & 30.9 & 82.3 & 115.4 & 775.5 \\
\hline Kani_Masi & 144.1 & 106.1 & 145.9 & 96.0 & 52.4 & 5.6 & 0.3 & 1.3 & 10.8 & 69.2 & 94.7 & 156.4 & 882.8 \\
\hline
\end{tabular}




\section{RESULTS \& DISCUSSIONS}

Evidently, study rainfall-runoff erosivity factor have a prominent role in soil management and erosion purposes, especially in case mutations of rainfall distribution. Conspicuously erosivity factor $(\mathrm{R})$ in conjunction with rainfall intensity and distribution of rainfall of any region. In line with this, the current research was a focus on the study the real coincident of (R) with geographical feature factor especially altitude at all study sites. Fig (2) shows the slope map that was interpolated from DEM. It is obvious that the study area is mountainous and ground elevation is increased from southwest to northeast, it was between $545 \mathrm{~m}-1282 \mathrm{~m}$.

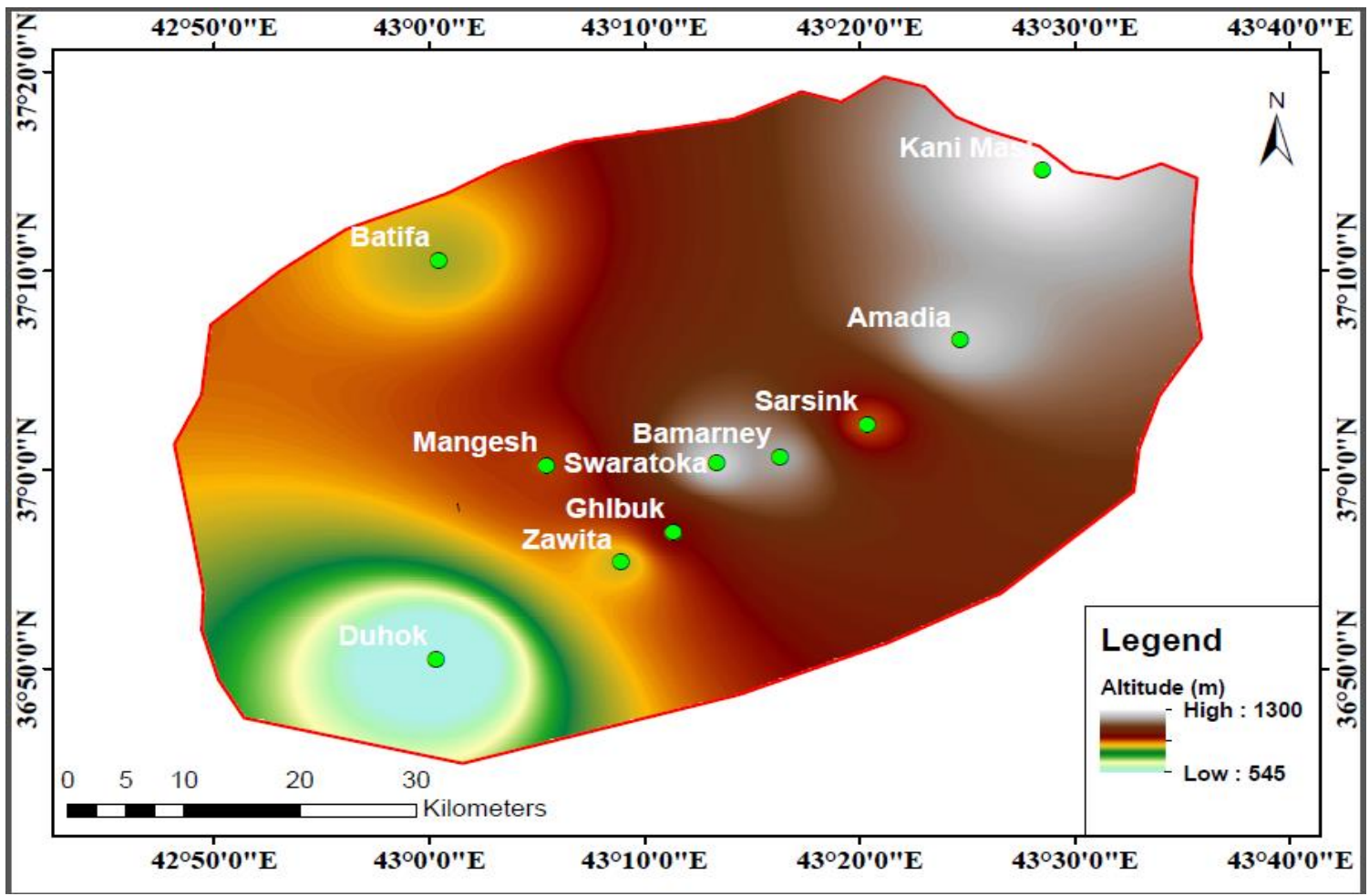

Fig. (2): altitudes in the study stations

In table (3) depicted the $\mathrm{P}$ value, MFI and $\mathrm{R}$ values in all the ten sites, the total precipitations were ranged from $(548.2 \mathrm{~mm}$ to $1038.8 \mathrm{~mm}$ ) Duhok and Sarsink station respectively, while the MFI from ( $80.01 \mathrm{~mm}$ to $147.37 \mathrm{~mm}$ ) in both
Duhok and Sarsink, finally the $\mathrm{R}$ factor in Duhok lowest value (184.28 MJ.cm/ha. hr. Year) compare to Sarsink gave the highest value (436.04 MJ.cm/ha. hr. Year). 
Table (3): Rainfall and Erosivity factors with MFI at different altitude sites.

\begin{tabular}{lccccc}
\hline No. & Stations & $\mathrm{P}(\mathrm{mm})$ & $\mathrm{MFI}(\mathrm{mm})$ & $\begin{array}{c}\mathrm{R}(\mathrm{MJ} . \mathrm{cm} / \mathrm{ha} . \mathrm{hr} . \\
\text { year })\end{array}$ & Altitude $(\mathrm{m})$ \\
\hline 1 & Duhok & 548.2 & 80.01 & 184.28 & 569 \\
\hline 2 & Zawita & 820.8 & 126.00 & 353.26 & 890 \\
\hline 3 & Glbuk & 784.2 & 97.75 & 244.42 & 996 \\
\hline 4 & Swaratoka & 791.2 & 108.15 & 281.86 & 1211 \\
\hline 5 & Mangesh & 787.7 & 112.06 & 296.34 & 957 \\
\hline 6 & Sarsink & 1038.8 & 147.37 & 436.04 & 1019 \\
\hline 7 & Bamarney & 845.9 & 119.04 & 322.69 & 1164 \\
\hline 8 & Amadia & 857.8 & 115.57 & 309.51 & 1202 \\
\hline 9 & Batifa & 775.5 & 108.54 & 283.30 & 879 \\
\hline 10 & Kani_Masi & 882.8 & 111.27 & 293.40 & 1281 \\
\hline
\end{tabular}

The R-factor maps reveal high spatial variability with elevated values in the study sites as shown (Panagos et at., 2016).
Highly relationship was illustrated between mean annual rainfall and MFI with $\mathrm{r}^{2}$ value equal (0.82) Fig (3) (Amoldus, 1980),

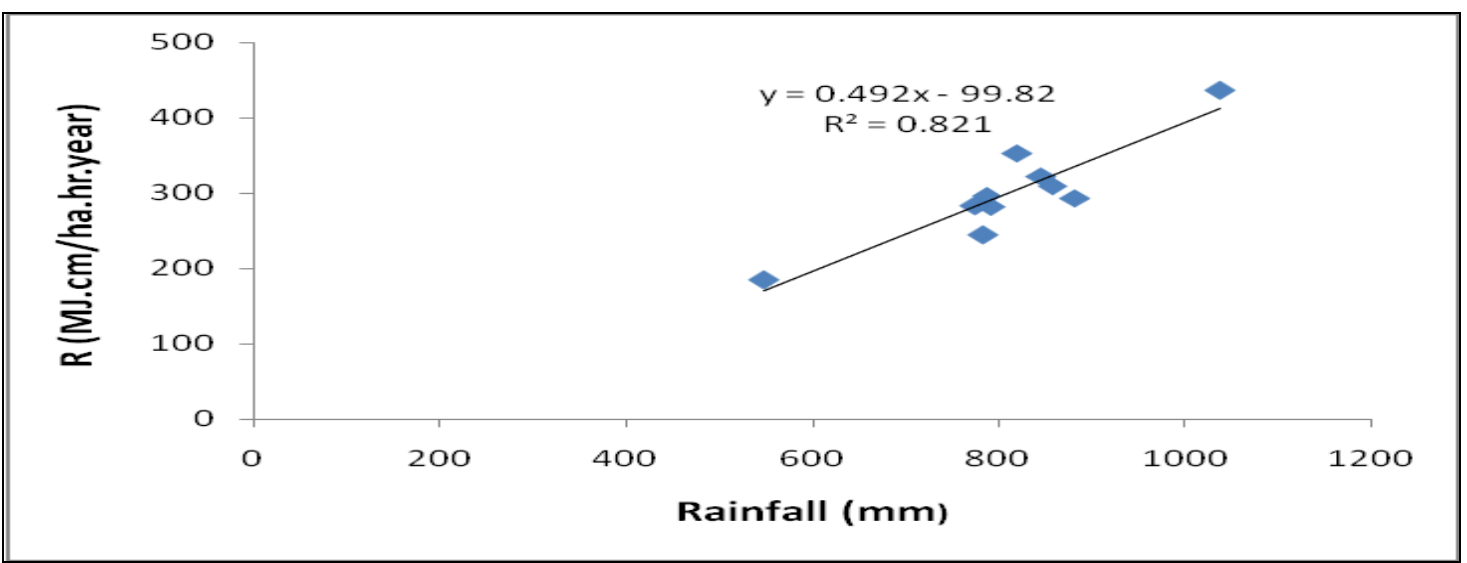

Fig. (3): Relationship between Rainfall and Erosivity factor

Where as strong relation was obtain between MFI values and erosivity factor $\left(r^{2}\right.$ $=0.98$ ) as show in Fig (4). Highly intense has close links of rainfall that reflect the high value of MFI which compatible with erosivity of study locations as shown that in table (3) this helps conveniently and virtually possibility of rainfall erosivity map in Fig (6).

Conspicuously, the relationship between $(\mathrm{R})$ and altitude was weak linear relation as showing in $\left(r^{2}=0.168\right)$ Fig (5), but this result is computable with that show by (Brychta and

Janeček 


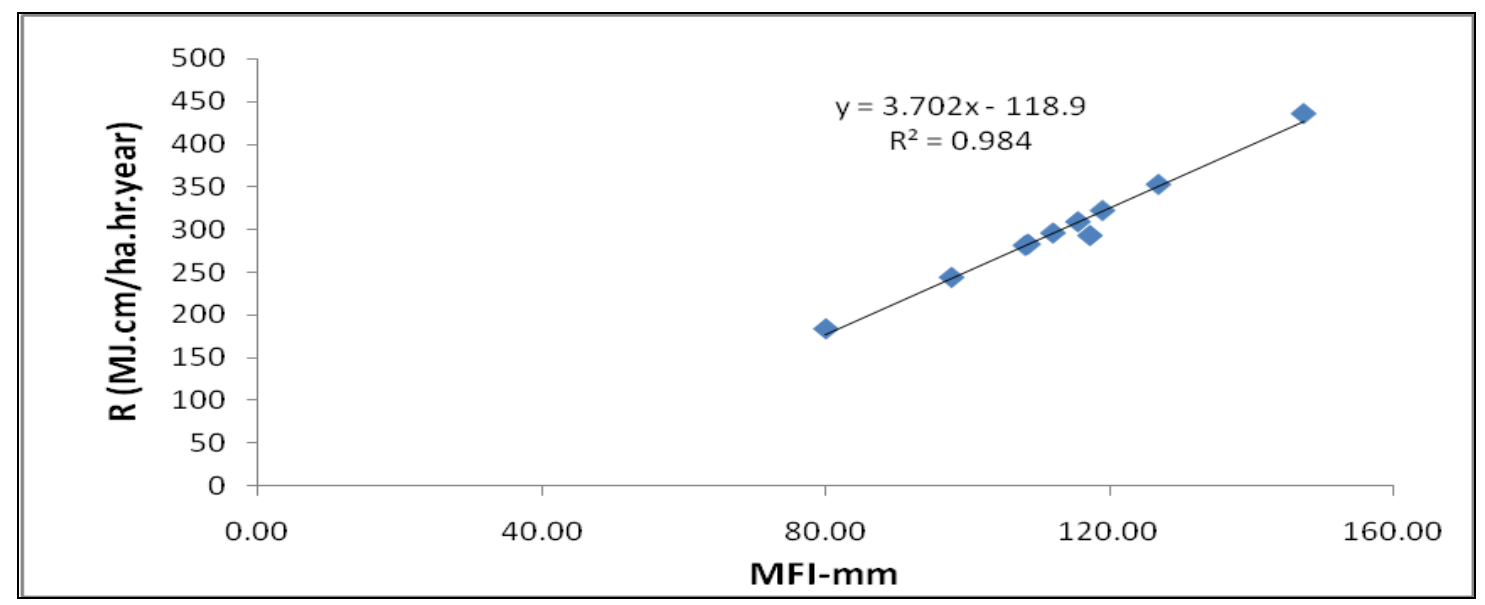

Fig. (4): Relationship between Erosivity and Modify Fournier index

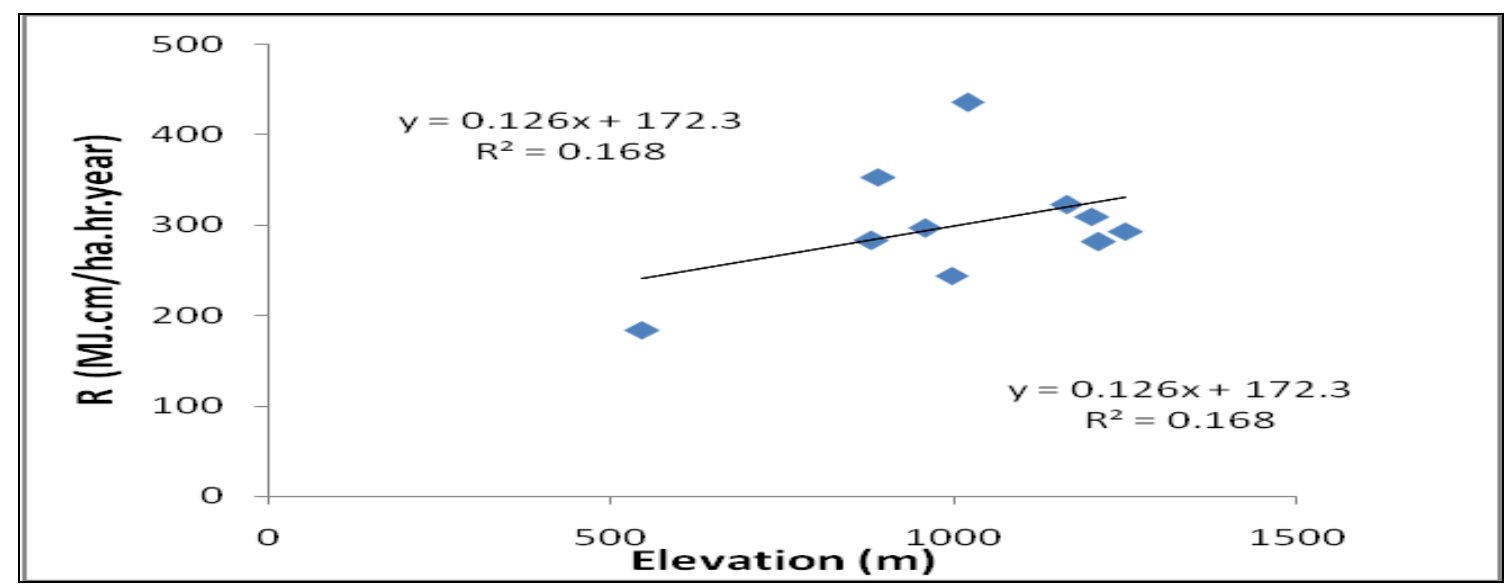

Fig. (5): Relationship between Erosivity and altitude

The elevation of sea level of both stations Kani_ Masi and Sarsink showed contradictory results, the lower value of sea level at Sarsink gave high value of $\mathrm{R}$. Whereas the high level of Kani_ Masi gave low R-value, this is due to two different factors reasons, the first one refers to the technical reasons which related to the accuracy of the rainfall gauge devices, where the second one, Sarsink has a direct relation with the natural of topography and the precipitation distribution.

Fig (6A) Indicates the six rainfall erosivity classes the lowest value was less than (200
MJ.cm/ha. hr. year) and the highest value was more than (400 MJ.cm/ha. hr. year). While in the Fig (6B) that related to the spacial pattern map ranged (184.28 MJ.cm/ha. hr. year) to $(436.04$ MJ.cm/ha. hr. year) ( Sadeghi et al., 2017). Lastly the Fig (6C) indicates to three classes low erosivity show in (Duhok), moderate erosivity show (Glbuk, Swaratoka, Mangesh, Bamarney, Amadia and Kani-Masi) while the high erosivity show in (Zawita and Sarsink) (Foster et al., 1981). 


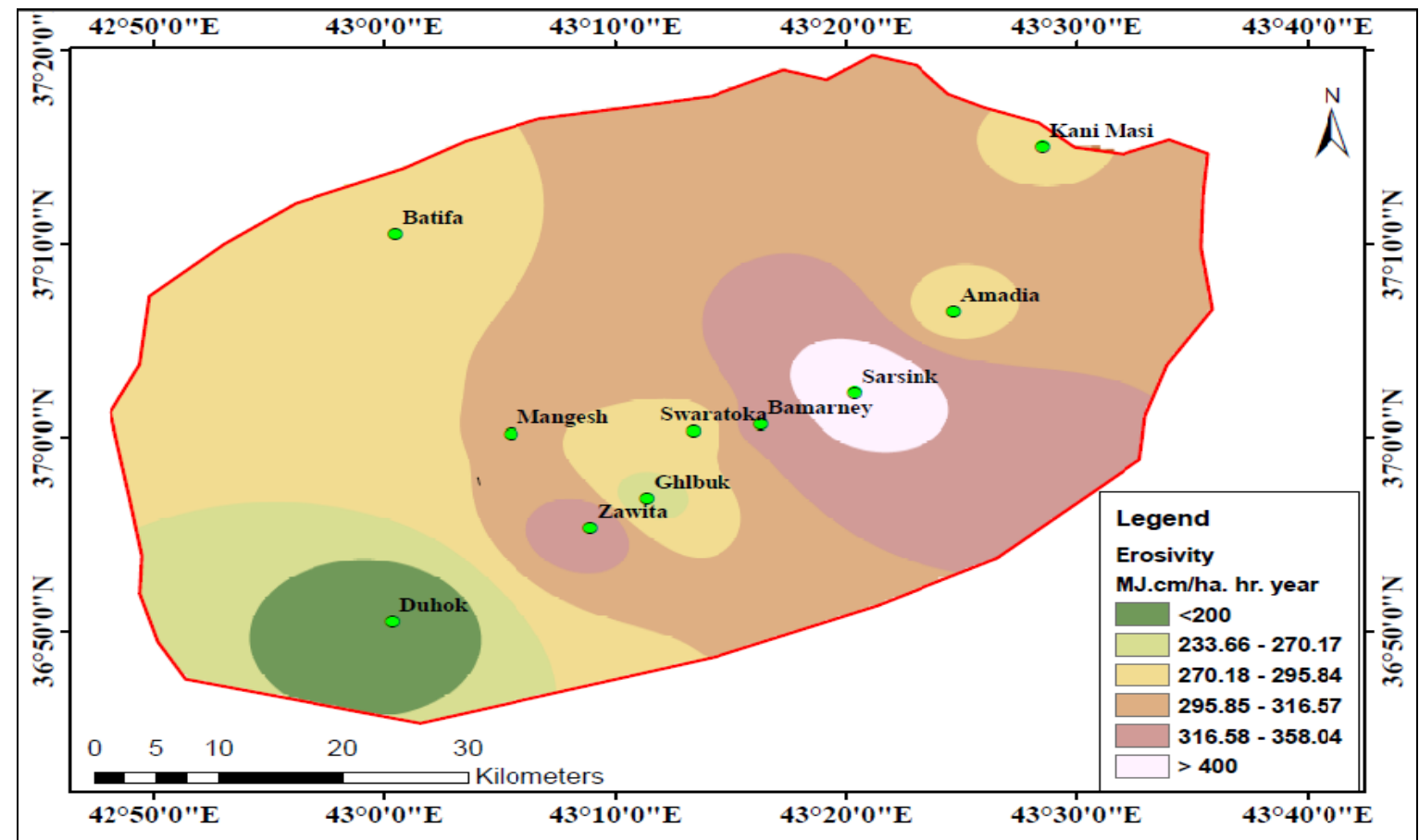

A
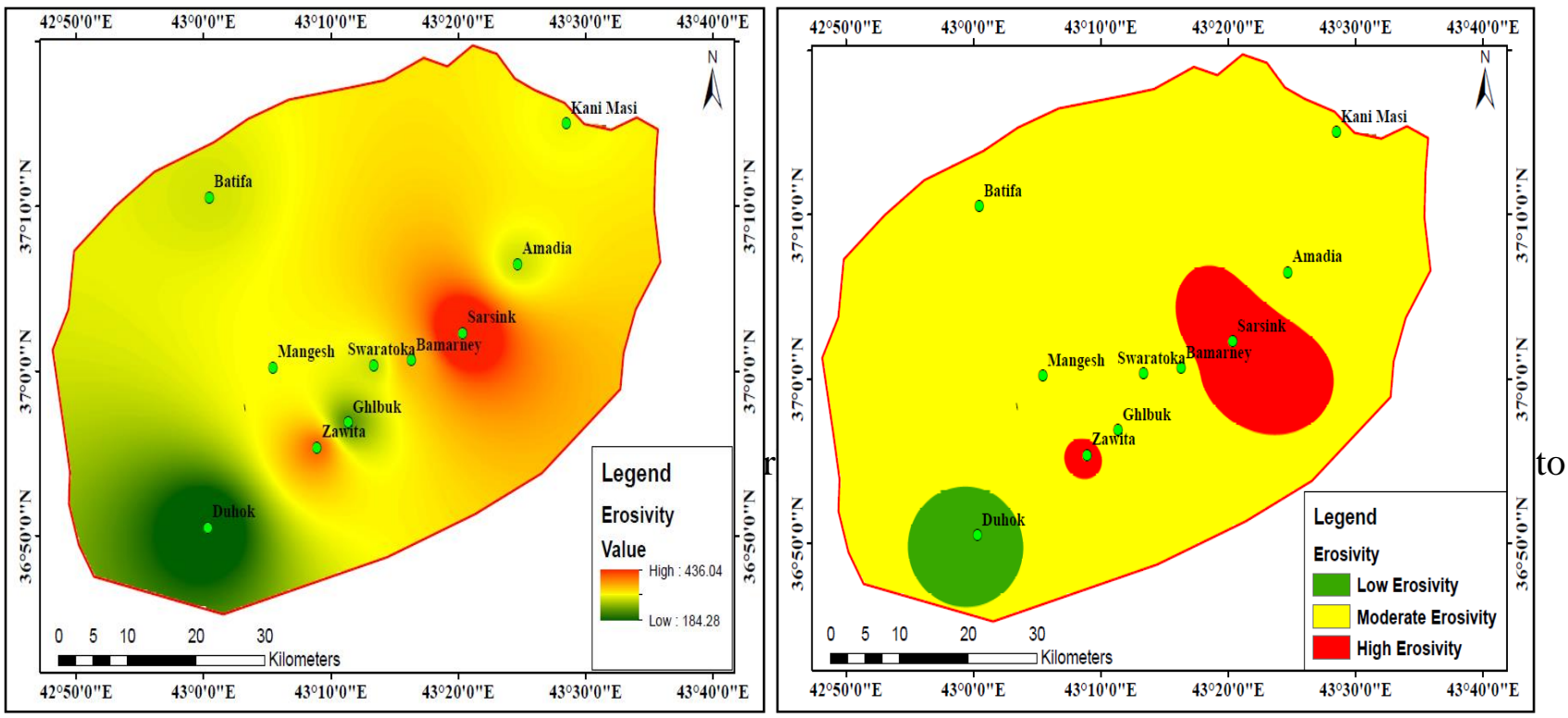


\section{CONCLUSION}

Results show that the relationship between Rvalue and altitudes was very weak (0.168). The reason is related to many factors, rainfall distribution in the study region, while other factors are due to associated with technical reasons.

In the other the relationship between $\mathrm{R}$ and rainfall values shows a significant one, it was a moderately strong $\left(\mathrm{R}^{2}=0.821\right)$. This means that rainfall can be used to estimate $\mathrm{R}$ but we cannot use altitude to predict $\mathrm{R}$.

\section{4- REFERENCES}

Arnoldus, H. M. J. (1980). An approximation of rainfall factor in the Universal Soil Loss Equation. In Assessment of Erosion, 127132. M. De Boodt and D Gabriels, eds. New York, N.Y.: John Wiley and Sons.

Brychta J., Janeček M. (2017). Evaluation of discrepancies in spatial distribution of rainfall erosivity in the Czech Republic caused by different approaches using GIS and geostatistical tools. Soil \& Water Res.

Elwell, H.A. \& Stocking, M.A. (1975). Parameters for estimating annual runoff and soil loss from agricultural lands in Rhodesia. Wat. Resour. Res.11 (4), 601605.

Elwell, H.A. (1981). A soil loss estimation technique for southern Africa, in soil conservation: problems and prospects, 281-292 edited by R.P.C. Morgan, Wiley, Chichester, Susseoc.

Foster, G.R., McCool, D.K., Renard, K.G. \&Moldenhauer, W.C., (1981). Conversion of the universal soil loss equation to SI metric units. Journal of Soil and Water Conservation 36, 355-359.

Goovaerts, P. (1999).Using elevation to aid the geostatistical mapping of rainfall erosivity.Catena. 34: 227-242.
Hudson, N.W. (1971). Soil conservation.Cornell UniversityPress, Ithaca, New York.

Khorsandi N., M. H. Mahdian, E. Pazira, D. Nikkami\&ChamheidarH. (2012). ComparisonofDifferent Interpolation Methods for Investigating Spatial Variability of Rainfall ErosivityIndex.Pol.J. Environment.Vol. 21, 6: 1659-1666.

Kingu, P.A. (1980).World map of erosivity, MSc thesis Ms/80/190, national college of agricultural engineering.

L'opez-Vicente, M., Navas, A., \&Mach'ın, J. (2008). Identifying erosive periods by using RUSLE factors in mountain fields of the Central Spanish Pyrenees, Hydro. Earth Syst. Sci., 12, 523-535.

Lal, R. (1975). Soil erosion problems on Alfisol in western Nigeria and their control.11T.A. Monograph No.1.

Lim, K. J., Sagong, M., Engel, B. A., Tang, Z., Choi, J., \& Kim, K. (2005). GIS-based sediment assessment tool, Catena, 64, 6180.

Lo, A., El-Swaify, S.A., Dangler E.W. \&Shinshiro, L. (1985). Effectiveness of $\mathrm{EI}_{30}$ as an erosivity index in Hawaii. In: Soil erosion and conservation (ed. by A. El-Swaify, W. C. Moldenhauer and A. Lo), Soil Conservation Society of America, Ankeny, pp. 384-392.

Mart'inez M. A., M. L' opez-Vicente. M. Vicente-Serrano, \&Beguer'1aS. (2009). Mapping rainfall erosivity at a regional scale: a comparison of interpolation methods in the Ebro Basin (NE Spain). Hydrol. Earth Syst. Sci. Discuss. 6: $417-$ 453.

Mello, C.R, M.R. Viola S. Beskow\& Norton L.D. (2013). Multivariate models for annual rainfall erosivity in Brazil. Geoderma. (202-203) 88-102.

Morgan, R. P. C. (1974). Estimating regional variation in soil erosion hazard in 
peninsular Malaysia, Malaysia nature journal, 28: 94-106.

Nikolov, (1983). Soil conservation expert worked on the effect of rainfall erosion in north Iraq an aid to soil conservation. By theexcept of republic of Iraq- ministry of agriculture and agrarian reform. General establishment for applied. Agricultural research.

Panagos, P., Imeson, A.,Meusbugber, K.,Borrell. P., Poeson,J.\&Alewell, C. (2016).Soil conservation in Eurrope wish or reality? Land Degrad. Dev.27, 1547-1661.

Renard, K.G. \&Freimund,J.R. (1994). Using monthly precipitation data to estimate the $\mathrm{R}$-factor in the revised USLE. Journal of Hydrology 157 (1-4): 287-306.
- Sadeghi S H, M Zabihi, M. Vafakhah and Hazbavi Z. (2017) Spatiotemporal mapping of rainfall erosivity index for different return periods in Iran. Nat Hazards -017-2752-3.

Sheridan, G. J. \& Rosewell, C. J. (2003). "An improved Victorian erosivity map", Australian Journal of Soil Research, Vol. 41, pp. 141-149.

Wischmeier, W. H. \& Smith, D. D. (1978). Predicting Rainfall Erosion Losses, a guide to conservation planning.Agro.Handbook N 537, USDA, Wash. D.C., 58 pages.

Yu, B. \&RosewellC.J. (1996). A robust estimation of the R-factor for the universal soil loss equation. T. ASAE. 39(2):559561. 


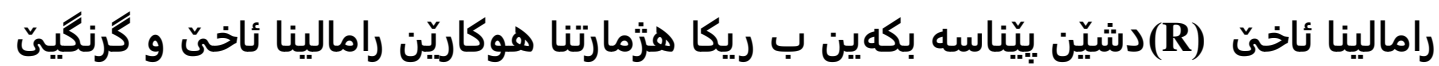

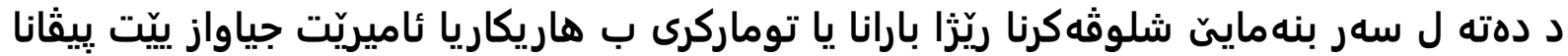

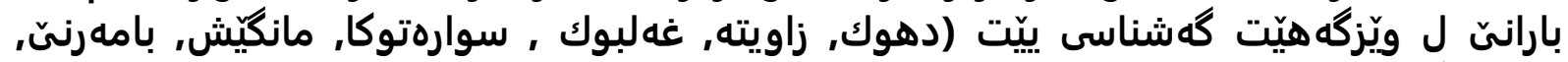

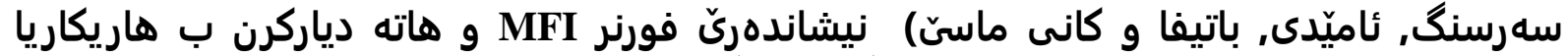

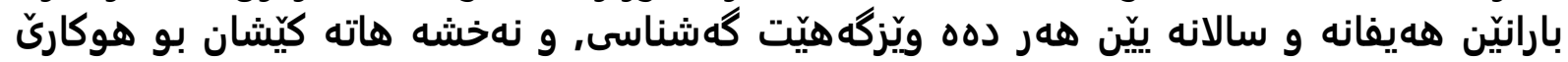

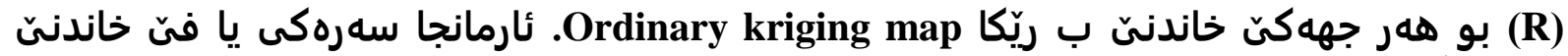

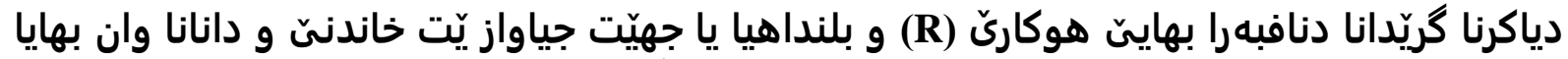

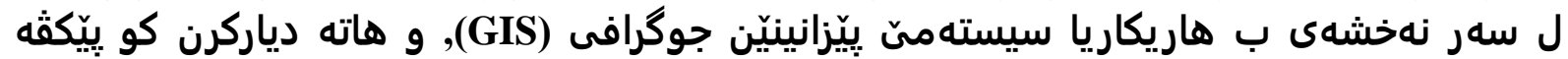

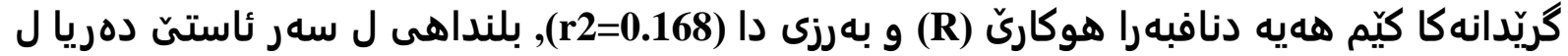

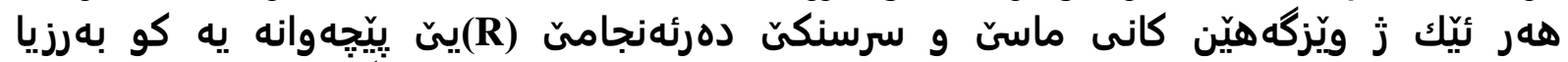

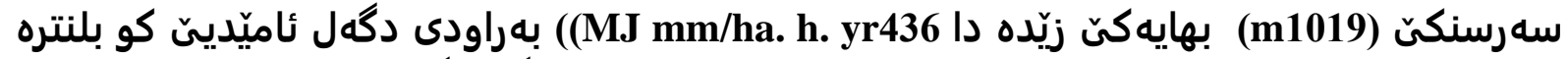

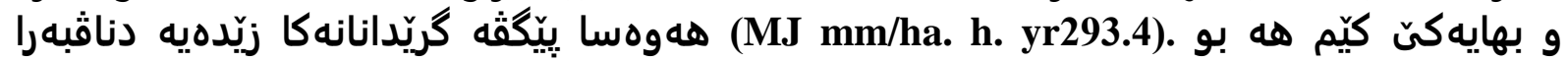
هوكاريّ (R) و باراني دا=

خارطة عامل قابلية المطر على التعرية للمواقع ذات الأرتفاعات مختلفة في محافظة دهوك

الخلاصة

يمكن تعريف عامل قابلية المطر على التعرية (R) من خلال حساب معامل تعرية التربة

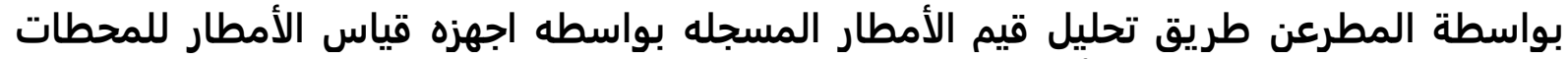

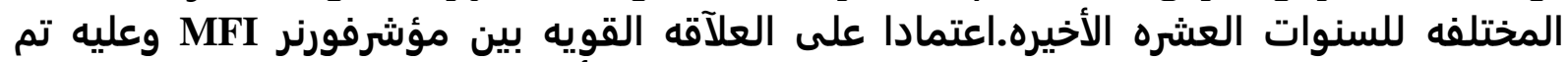

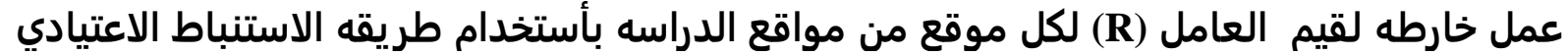
(Ordinary kriging map) الأساسي لهذه الدراسه هي ايجاد مدى الأرتباط بين قيم العامل (R) والأرتفاع المختلفه لمواقاتع

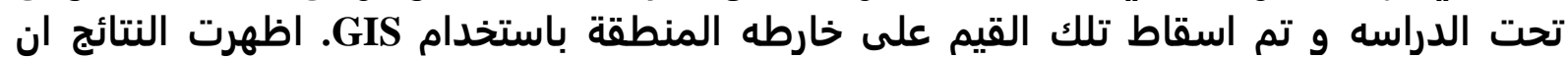

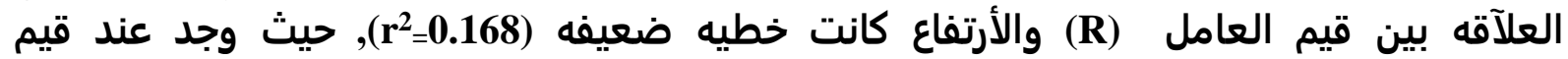

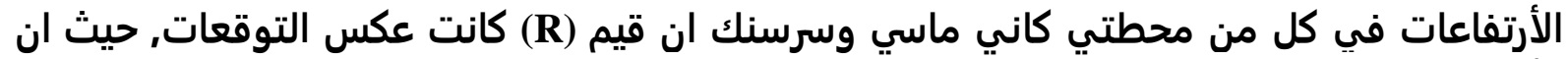

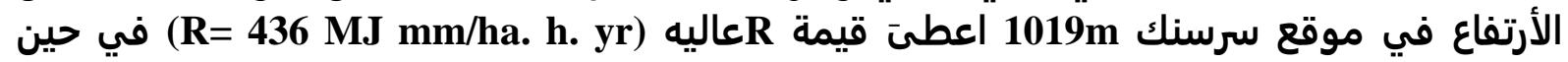

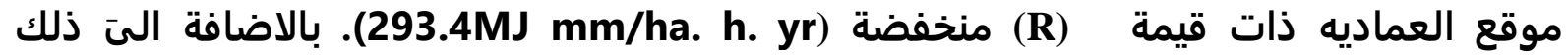
اظهرت النتائج ان هناك علاقة قوية بين كل من (R) والامفة (R) والامطارالسنويه وكانت (r=0.821). 